\title{
Effects of plastic sheet on water saving and yield under furrow irrigation method in semi-arid region
}

\author{
Muhammad Sohail Memon ${ }^{1,2}$, Kausar Ali $^{2}$, Altaf Ali Siyal ${ }^{3}$, Jun Guo ${ }^{4}$, Shamim Ara Memon², \\ Shakeel Ahmed Soomro ${ }^{2}$, Noreena Memon ${ }^{2}$, Changying $\mathrm{Ji}^{{ }^{*}}$ \\ (1. College of Engineering, Nanjing Agricultural University, Nanjing 210031, China; 2. Faculty of Agricultural Engineering, \\ Sindh Agriculture University Tandojam 70060, Pakistan; 3. U.S.-Pakistan Center for Advanced Studies in Water (USPCAS-W), \\ Mehran University of Engineering and Technology, Jamshoro, Sindh 76062, Pakistan; \\ 4. Yancheng Vocational Institute of Industry Technology, Yancheng 224005, China)
}

\begin{abstract}
The increasing demand of water in the country highlights the need to introduce low-input and water saving technologies for agricultural sustainability and crop production, mainly in semi-arid region. A study was conducted to minimize deep percolation losses from the furrow bottom under two different irrigation treatments viz. (1) furrow bottom with plastic sheet $\left(\mathrm{T}_{1}\right)$ and (2) furrow bottom without plastic Sheet $\left(\mathrm{T}_{0}\right)$. The physical and chemical analyses of soil profile were taken at a depth of 0-80 $\mathrm{cm}$ before and after crop harvesting. The dry density of soil slightly increased $\left(0.01 \mathrm{~g} / \mathrm{cm}^{3}\right)$ under both treatments, while soil $\mathrm{pH}$ decreased under $\mathrm{T}_{1}$. The average yield was $8332 \mathrm{~kg} / \mathrm{hm}^{2}$ and $7575 \mathrm{~kg} / \mathrm{hm}^{2}$, with $21.56 \mathrm{~m}^{3}$ and $31.09 \mathrm{~m}^{3}$ total volume of irrigation water applied under $\mathrm{T}_{1}$ and $\mathrm{T}_{0}$, respectively. The saving percentages of water under treatments were $52.22 \%$ and $31.00 \%$ under $\mathrm{T}_{1}$ and $\mathrm{T}_{0}$ respectively as compared to the saving of water under traditional irrigation practice. Overall, better performance, in terms of crop production and water saving, was obtained with use of plastic sheet integrated with bottom of furrows. Hence, it is suggested that the furrow irrigation method with plastic sheet may be used to preventing moisture and minimize deep percolation losses from furrow bottom.
\end{abstract}

Keywords: furrow irrigation, semi-arid region, water saving, yield, plastic sheet, deep percolation, okra crop, soil pH DOI: $10.25165 /$ j.ijabe.20181101.3186

Citation: Memon M S, Ali K, Siyal A A, Guo J, Memon S A, Soomro S A, et al. Effects of plastic sheet on water saving and yield under furrow irrigation method in semi-arid region. Int J Agric \& Biol Eng, 2018; 11(1): 172-177.

\section{Introduction}

Pakistan is an agriculture country, which falls within semi-arid to arid climatic zones. Its irrigated areas are under the pressure of water shortage while the rain-fed areas are severely affected by drought ${ }^{[1,2]}$. However, under these circumstances, the proper use of water resources with ideal outputs should be important and the basic objective for sustainable agricultural production ${ }^{[3,4]}$. The increasing demand of water for irrigation supply in the country

Received date: 2017-01-08 Accepted date: 2017-11-06

Biographies: Muhammad Sohail Memon, $\mathrm{PhD}$ candidate, research interests: agricultural water management, soil and tillage, agricultural sustainability and remote sensing applications, Email: engr.sohailm@yahoo.com; Kausar Ali, Graduate candidate, research interests: agricultural engineering, water saving and water management, Email: engr_kausar35@yahoo.com; Altaf Ali Siyal, PhD, Professor, research interests: water flow and solute transport in the vadose zone, remote sensing \& GIS applications in natural resources management and efficient use of irrigation water, Email: aasiyal.uspcasw@faculty.muet.edu.pk; Jun Guo, PhD, Assistant Professor, research interests: soil tillage engineering, soil science and irrigation, Email: gj_njau@163.com; Shamim Ara Memon, Assistant Professor, research interests: irrigation \& drainage, crop water requirement, soil science and water management, Email: soni_mem@yahoo.com; Shakeel Ahmed Soomro, Lecturer, research interests: agricultural engineering, crop science and food engineering, Email: shakeelsoomro@live.com; Noreena Memon, Graduate candidate, research interests: agricultural engineering and water management, Email: engr.noreena@yahoo.com.

*Corresponding author: Changying $\mathbf{J i}, \mathrm{PhD}$, Professor, research interests: agricultural mechanization engineering, soil science, machine design, soil tillage, robotic engineering and soil-water engineering. College of Engineering, Nanjing Agricultural University, Nanjing 210031, China. Tel: $+86-25-58606571$, Email: chyji@njau.edu.cn. emphasizes the important need to introduce low-input and water saving technologies for agricultural sustainability and crop production, mainly in arid and semi-arid areas ${ }^{[5,45]}$.

Agriculture sector remains as the domination of water requirements for the irrigation purpose ${ }^{[6]}$. Moreover, semi-arid and arid regions of the country with the increasing population, urbanization and unsustainable consumption of water have further imposed the greater demands of water ${ }^{[7,8]}$. Thus, it becomes indispensable to properly manage water resources at all levels in order to fulfill food and fiber requirements of growing population. The growing demand for water aimed to improve the overall efficiency of the system with particular approach focus on increasing water use efficiency (WUE) at field level ${ }^{[9,10]}$.

In Pakistan Basin, border and furrow are the traditional surface irrigation methods, which are used to irrigate crops ${ }^{[11,12]}$. Closely related furrow irrigation is the surface irrigation which utilizes the water for irrigation more efficiently as compared to other surface irrigation methods ${ }^{[13]}$. Furrow irrigation is the water shortage technique which considerably improves WUE, reduces irrigation, increases crop production with the shortage of water supply, and has low permeability and less seasonal water logging condition ${ }^{[14]}$. The method is suitable for row crops which are sensitive to standing water and the crop is planted on the ridges between furrows, which may contain a single row of plants ${ }^{[13]}$. Furrow irrigation provides better on-farm water management capabilities, reduces the flow rates per unit width, and is applicable to more severe and variable topographical conditions ${ }^{[15]}$. In addition, the operational flexibility is also important for achieving higher efficiency for each irrigation method throughout a season ${ }^{[9,16]}$. 
Mugnozza et al. ${ }^{[17]}$ reported that the use of plastic sheet mulch in agriculture sector is a global phenomenon with an increasing trend. Use of plastic sheet mulch in agriculture is beneficial to soil physical, biological and chemical conditions for better crop performance ${ }^{[18,19]}$. The using of the plastic sheet at furrow bottom can reduce the loss of fertilizer and nutrient through leaching, and provide a barrier to soil pathogens ${ }^{[3,20]}$. Plastic sheet decreases the germination of weeds and repel certain insects. Additionally, plastic sheet provides a stable environment especially at night to promote seed germination ${ }^{[21]}$. Rodrigues et al. and Jin et al. ${ }^{[22,23]}$ studied that the using of plastic sheet in agriculture was mainly employed for the reduction of irrigation frequency and water saving.

Bai et al. ${ }^{[24]}$ reported that micro-collecting practice of rainwater increased the WUE as compared to the plastic sheet used for flat planting practice and the conventional planting practice. Wang et al. and Fang et al. ${ }^{[25,26]}$ showed that the WUE and potato production improved significantly under plastic sheet treatment and ridge planting. Wang et al. ${ }^{[27]}$ reported that the using of plastic sheet was capable of promoting deep soil water, improving crop growth, accelerating the soil-plant-atmosphere transport and significantly improving crop WUE. Hatami et al. ${ }^{[2]}$ examined that the using of plastic mulch treatments in the field had significantly increased the yield and yield ingredients, affecting the traits of tomato and weed species.

Jiang et al. ${ }^{[28]}$ conducted a study and indicated that the percentage of WUE and water saving of mung bean were higher by $22.73 \%-40.38 \%$ as compared with those of flat farming practice. Rong et al. ${ }^{[29]}$ conducted an experiment to determine the influence of ridge-and-furrow rainfall harvesting systems using plastic film in different patterns on water-use efficiency and maize yield. The results indicated that higher maize yield and water-use efficiency was found with plastic film up to $35 \%$, while the average water-use efficiency increased by 30\%, whereas okra (Abelmoschus-esculentus L) was proposed as an indicator crop cultivated in field plot, which was an important vegetable sown in sub-tropical and tropical regions of world. Okra is rich in vitamins, calcium, potassium and other minerals matter and is an important vegetable crop of the summer season cultivated using furrow irrigation method. In view of the importance of plastic film sheet in water conservation practice, this study was performed with the use of plastic sheet to cover furrow bottom under furrow irrigation method for effective use of water as compared to without plastic sheet under furrow irrigation method. The aim of this study was to evaluate the water saving with furrow irrigation method by minimizing infiltration from the furrow bottom and impact on the crop growth and yield using plastic sheet at furrow bottom.

\section{Materials and methods}

\subsection{Description of the experimental site}

The present study was conducted at the experimental site of Faculty of Agricultural Engineering, Sindh Agriculture University Tandojam, Sindh Pakistan (Figure 1) during May-July, 2014-2015. The field is located at Latitude of $25.2528^{\circ} \mathrm{N}$ and Longitude of $68.3224^{\circ} \mathrm{E}$ at an elevation of $26 \mathrm{MSL}$, while the irrigation water supply was ground water. The meteorological data, i.e., mean monthly temperature, rainfall and pan evaporation rate were collected from the metrological observatory of Drainage Reclamation Institute of Pakistan (DRIP) Tandojam. The average monthly temperature were recorded $34.7^{\circ} \mathrm{C}, 33.8^{\circ} \mathrm{C}$, and $33.6^{\circ} \mathrm{C}$ and $10.40 \mathrm{~mm}, 10.27 \mathrm{~mm}$, and $9.95 \mathrm{~mm}$ were noted for the average monthly evaporation rates for May, June, and July respectively. The rainfall was $0.17 \mathrm{~mm}$ during the entire crop growth period in the experimental area.

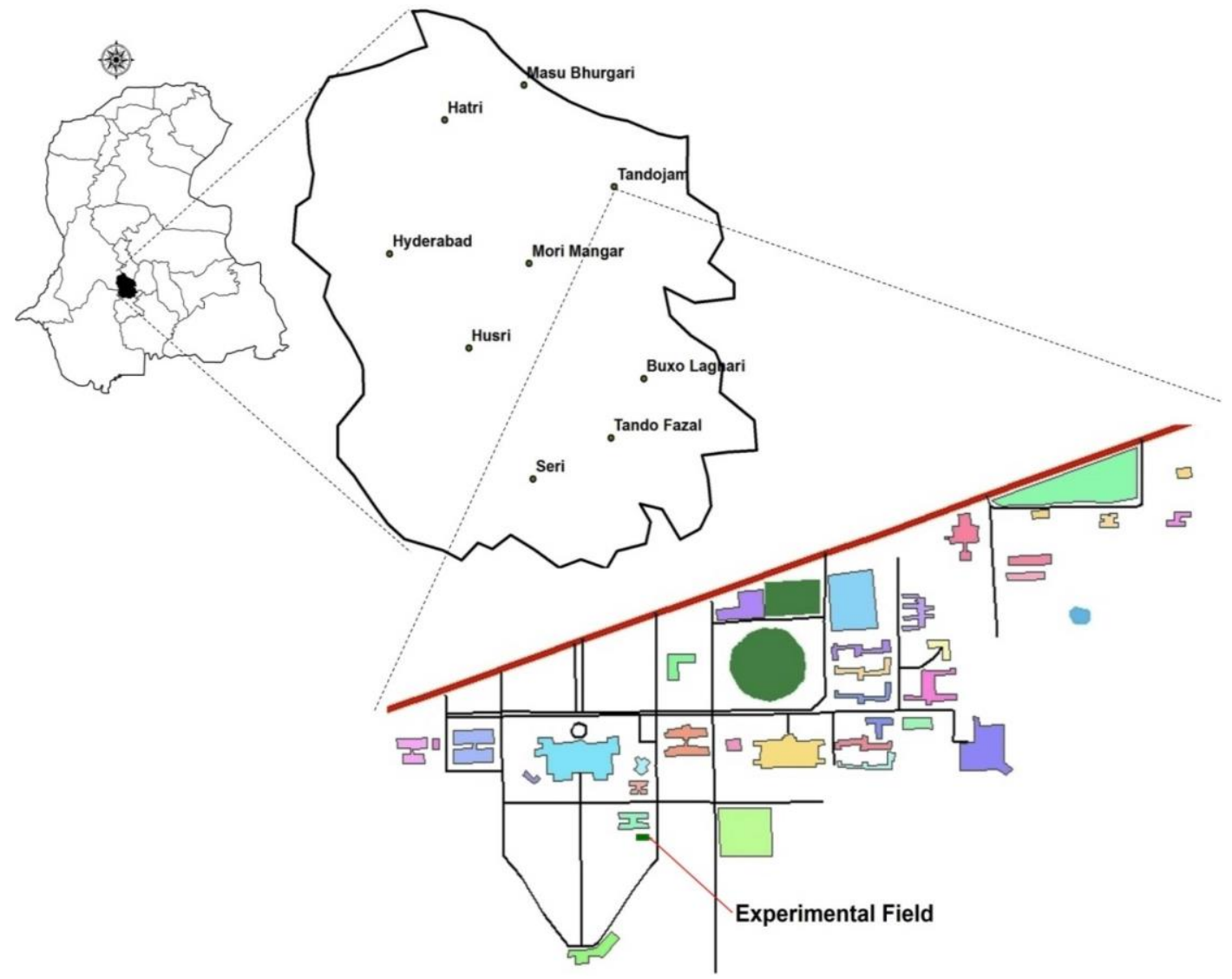

Figure 1 Geographical location of study site 


\subsection{Experimental design and layout}

The plot selected for the experiment was of size $12 \mathrm{~m} \times 11 \mathrm{~m}$ $\left(132 \mathrm{~m}^{2}\right)$ and each treatment $\left(\mathrm{T}_{1}=\right.$ Furrow bottom with a plastic sheet and $\mathrm{T}_{0}=$ Furrow bottom without the plastic sheet) was arranged under Randomized Complete Block Design (RCBD) with six times replication.

\subsection{Land preparation}

The experimental site was arranged with the application of irrigation water for $80 \mathrm{~mm}$ as a soaking dose, whereas the seedbed was performed with ploughing of disc harrow and moldboard plough. After completion of each treatment, the length for each furrow was $11 \mathrm{~m}$ while the width for each ridge was $0.50 \mathrm{~m}$, and the plastic sheet film was placed to cover the furrow bottom in treatment $\mathrm{T}_{1}$.

\subsection{Crop parameters}

June to July and February to March are the two growing seasons of okra. The total water requirement for okra in whole growing season is $500 \mathrm{~mm}^{[30]}$. For enhancing the germination of okra yield, the seeds were soaked for 6-8 $\mathrm{h}$ in water before sowing. After the soaking period, the seeds were sown manually on both sides of ridges with a plant $x$ plant spacing of $25 \mathrm{~cm}$. The sowing date of the okra was $8^{\text {th }}$ May, 2014. All agronomic practices were kept normal and uniform for both treatments. Okra requires a long and warm climate and is susceptible to frost. The seed usually does not germinate when the temperature is below $20^{\circ} \mathrm{C}$. The plants started emerging after 3-4 $\mathrm{d}$ and were apparently visible after one week.

However, after the crop germination, the plants were thinned out at 3-5 leaf, whereas the irrigation was applied to both treatments with an interval of 6-8 d. The water consumed by each furrow during irrigation was measured with cut-throat flume under both experimental treatments and recorded the reading of irrigation water depth $(\mathrm{cm})$. While for measuring the plant growth of each treatment, randomly ten plants were selected and tagged, and plant height $(\mathrm{cm})$, growth rate $(\mathrm{cm})$ and a number of branched per plant were recorded, and then the average number was calculated respectively.

Fertilizers are one of the most important factors, which can increase crop yields. The chemical fertilizers were applied to all plots using recommended $\operatorname{dose}^{[30]}$ that phosphorous $(\mathrm{P})$ at the rate of $100 \mathrm{~kg} /$ acre $\left(1 \mathrm{acre}=0.40 \mathrm{hm}^{2}\right)$, potassium $(\mathrm{K}), 50 \mathrm{~kg} / \mathrm{acre}$, and nitrogen $(\mathrm{N})$ as urea, $55 \mathrm{~kg} / \mathrm{acre}$. Thus on the basis of experimental plot size, $10 \mathrm{~kg}$ of $\mathrm{P}_{2} \mathrm{O}_{5}$ and $5 \mathrm{~kg}$ of $\mathrm{K}_{2} \mathrm{O}$ were applied in both plots at sowing time, while $10 \mathrm{~kg}$ of $\mathrm{N}$ was applied $30 \mathrm{~d}$ later at pre-flowering stage. Okra is highly susceptible to a large range of insect pests and diseases for all growing areas ${ }^{[31]}$. During the vegetative growth stage, the crop was sprayed with Nitenpyramat at the rate of $200 \mathrm{~mL} /$ acre to kill the insects. The crop harvesting was mainly started in the first week of July, afterward okra pods were weighed separately and the yield data were converted into $\mathrm{kg} / \mathrm{hm}^{2}$ for experimental treatments.

\subsection{Soil sampling}

48 soil samples were taken from ridges with the help of auger sampler at different soil depths of 0-20 cm, 20-40 cm, 40-60 cm and $60-80 \mathrm{~cm}$. These samples were collected from each treatment separately before sowing and after harvesting of the crop and placed in plastic bags. Two samples were also taken for the soil dry density from both treatments at depth of $0-20 \mathrm{~cm}$ with core sampler. These soil samples were examined for following parameters as presented in Table 1.
Table 1 Physico chemical properties of studied soil

\begin{tabular}{clccc}
\hline S. No & \multicolumn{1}{c}{ Parameter } & Adopted Method & For & Reference \\
\hline 1 & Soil Texture & Bouyoucos hydrometer & Soil & {$[32]$} \\
2 & Dry Density $/ \mathrm{pd}$ & Core method & Soil & {$[33]$} \\
3 & $\mathrm{EC}_{\mathrm{e}} / \mathrm{dS} \cdot \mathrm{m}^{-1}$ & Soil saturation extract & Soil & {$[34]$} \\
4 & $\mathrm{pH}$ & Soil saturation extract & Soil & {$[34]$} \\
\hline
\end{tabular}

The flow rate was calculated using Equation (1), while the total required depth of water to be filled the furrows in each irrigation was measured by Equation (2) under both treatments ${ }^{[11]}$.

$$
\begin{gathered}
Q_{s}=\frac{\left[C_{s}\left(h_{u}-h_{d}\right) n_{f}\right]}{\left[(-\log S) n_{s}\right]} \\
Q T=A D
\end{gathered}
$$

In this study water saving was measured with or without plastic sheet at furrow bottom, and then compared with traditional irrigation method. The irrigation water in all treatments was calculated by the Equation (3) and (4), whereas the irrigation data for flood irrigation practices was taken from the literature ${ }^{[8]}$.

$$
\begin{aligned}
& W S(\%)=\frac{\left(W_{F L}-W_{F P}\right)}{W_{F L}} \times 100 \\
& W S(\%)=\frac{\left(W_{F}-W_{F P}\right)}{W_{F}} \times 100
\end{aligned}
$$

The total yield recorded from $\mathrm{T}_{0}$ was compared to $\mathrm{T}_{1}$ and these results were also compared with the results of flood irrigation method (from literature). Equation (5) and (6) were used for comparing the yield of okra crop.

$$
\begin{aligned}
& \operatorname{Yield}(\%)=\frac{\left(Y_{F L}-Y_{F P}\right)}{Y_{F L}} \times 100 \\
& \operatorname{Yield}(\%)=\frac{\left(Y_{F}-Y_{F P}\right)}{Y_{F}} \times 100
\end{aligned}
$$

\section{Results}

\subsection{Physicochemical properties of soil}

The soil samples were collected from different location of the each treatment plots at the depth of $0-80 \mathrm{~cm}$ and then the physical and chemical properties of soil were analyzed.

\subsubsection{Texture of soil profile}

The soil texture analysis revealed a non-significant variation of soil particles relative percentage at different depths, whereas the soil was loamy in texture according to the USDA Soil Taxonomy on depth of $0-80 \mathrm{~cm}$ under both treatment plots, which remained unchanged after the crop harvest.

\subsubsection{Dry density of soil profile}

The results of soil dry density (pd) for treatments $T_{0}$ and $T_{1}$ were presented in Table 2 . It was indicated that the value of dry density was $1.23 \mathrm{~g} / \mathrm{cm}^{3}$ before sowing and increased to $1.24 \mathrm{~g} / \mathrm{cm}^{3}$ after harvest under $\mathrm{T}_{0}$ at soil depths $0-20 \mathrm{~cm}$. Whereas, it was $1.19 \mathrm{~g} / \mathrm{cm}^{3}$ before sowing and increased to $1.20 \mathrm{~g} / \mathrm{cm}^{3}$ after harvest under $\mathrm{T}_{1}$ at soil depths $0-20 \mathrm{~cm}$, however the ANOVA revealed that soil dry density was non-significantly $(p>0.05)$ between both treatments.

\subsection{3 $\mathrm{pH}$ and $\mathrm{EC}_{\mathrm{e}}$ of soil profile}

The soil $\mathrm{pH}$ and $\mathrm{EC}_{\mathrm{e}}$ results data for both treatments $\left(\mathrm{T}_{0}\right.$ and $\left.\mathrm{T}_{1}\right)$ were depicted in Table 4. The data of $\mathrm{pH}$ in pre-sowing were in range of 8.1 to 8.5 , while for the post-harvest $\mathrm{pH}$ data are in the ranged from 7.8 to 8.3 for the treatments of $T_{0}$ and $T_{1}$ at the depths of $0-80 \mathrm{~cm}$ respectively. From the results of Table 4 showed that the $\mathrm{pH}$ of before crop sowing and harvest of $\mathrm{T}_{0}$ and $\mathrm{T}_{1}$ decreased at the soil depths from $0-80 \mathrm{~cm}$ respectively. 
Table 2 Dry density for both treatments

\begin{tabular}{|c|c|c|c|c|c|}
\hline \multirow{2}{*}{$\begin{array}{l}\text { Soil depth } \\
\quad / \mathrm{cm}\end{array}$} & \multicolumn{2}{|c|}{ Before sowing $/ \mathrm{g} \cdot \mathrm{cm}^{-3}$} & \multicolumn{3}{|c|}{ After-harvest $/ \mathrm{g} \cdot \mathrm{cm}^{-3}$} \\
\hline & $\mathrm{T}_{0}$ & $\mathrm{~T}_{1}$ & & $\mathrm{~T}_{0}$ & $\mathrm{~T}_{1}$ \\
\hline $0-20$ & 1.23 & 1.19 & & 1.24 & 1.20 \\
\hline Table 3 & \multicolumn{5}{|c|}{ ANOVA tests of between treatments } \\
\hline Source Variation & SS & $\mathrm{DF}$ & MS & $\mathrm{F}$ & P. \\
\hline $\mathrm{T}_{0}$ & 0.000 & 1 & 0.000 & 32.151 & 0.001 \\
\hline $\mathrm{T}_{1}$ & 0.002 & 1 & 0.002 & 161.608 & 0.000 \\
\hline Depth & 0.002 & 3 & 0.001 & 50.926 & 0.000 \\
\hline Error & 0.000 & 6 & 0.000 & & \\
\hline
\end{tabular}

Table 4 PH and $\mathrm{EC}_{\mathrm{e}}$ of soil profile for both treatments

\begin{tabular}{|c|c|c|c|c|c|c|c|c|c|}
\hline \multirow{3}{*}{ S. No } & \multirow{3}{*}{$\begin{array}{l}\text { Soil } \\
\text { Depths } \\
\text { /cm }\end{array}$} & \multicolumn{4}{|c|}{ Pre-sowing } & \multicolumn{4}{|c|}{ Post-harvest } \\
\hline & & \multicolumn{2}{|c|}{$\mathrm{pH}$} & \multicolumn{2}{|c|}{$\mathrm{EC}_{\mathrm{e}} / \mathrm{dS} \cdot \mathrm{m}^{-1}$} & \multicolumn{2}{|c|}{$\mathrm{pH}$} & \multicolumn{2}{|c|}{$\mathrm{EC}_{\mathrm{e}} / \mathrm{dS} \cdot \mathrm{m}^{-1}$} \\
\hline & & $\mathrm{T}_{0}$ & $\mathrm{~T}_{1}$ & $\mathrm{~T}_{0}$ & $\mathrm{~T}_{1}$ & $\mathrm{~T}_{0}$ & $\mathrm{~T}_{1}$ & $\mathrm{~T}_{0}$ & $\mathrm{~T}_{1}$ \\
\hline 1 & $0-20$ & 8.2 & 8.4 & 1.15 & 0.39 & 7.8 & 7.9 & 1.70 & 1.39 \\
\hline 2 & $20-40$ & 8.5 & 8.3 & 0.66 & 0.30 & 8.0 & 8.1 & 1.21 & 1.60 \\
\hline 3 & $40-60$ & 8.4 & 8.2 & 0.47 & 0.32 & 8.3 & 8.0 & 0.57 & 1.42 \\
\hline 4 & $60-80$ & 8.1 & 8.2 & 0.42 & 0.60 & 8.0 & 7.9 & 0.59 & 0.61 \\
\hline
\end{tabular}

It was indicated that the values of $\mathrm{EC}_{\mathrm{e}}$ were ranged from $0.30 \mathrm{dS} / \mathrm{m}$ to $1.15 \mathrm{dS} / \mathrm{m}$ pre-sowing and were noted in the range of $0.57 \mathrm{dS} / \mathrm{m}$ to $1.70 \mathrm{dS} / \mathrm{m}$ for the treatments $\mathrm{T}_{0}$ and $\mathrm{T}_{1}$ at the depths of $0-80 \mathrm{~cm}$. The results from Table 4 showed that $\mathrm{EC}_{\mathrm{e}}$ of soil saturation increased after harvest at the treatment $\mathrm{T}_{1}$ at the soil depths of $0-80 \mathrm{~cm}$, while the analysis of variance revealed that the $\mathrm{EC}_{\mathrm{e}}$ of soil at different depths was significantly $(p<0.05)$.

\subsection{Crop growth and yield parameter}

The plant heights and number of branches per plant were presented in Table 5. The analysis of variance showed that the plant heights and number of branches per plant for selected 10 different plants were significantly changed by using plastic sheet at furrow bottom. It was determined that the average values of plant height were noted $16.35 \mathrm{~cm}(p<0.05), 36.35 \mathrm{~cm}(p<0.05)$ and $47.10 \mathrm{~cm}(p<0.05)$ under treatment $\mathrm{T}_{0}$ and $17.30 \mathrm{~cm}(p<0.05)$, $36.85 \mathrm{~cm}(p<0.05)$ and $51.10 \mathrm{~cm}(p<0.05)$ were recorded for the treatment $\mathrm{T}_{1}$ on $3^{\text {rd }}, 6^{\text {th }}$ and $9^{\text {th }}$ irrigation respectively.

Table 5 Plant heights and branches per plant for both treatments

\begin{tabular}{|c|c|c|c|c|c|c|}
\hline \multirow{2}{*}{ Treatments } & \multicolumn{2}{|c|}{$3^{\text {rd }}$ Irrigation } & \multicolumn{2}{|c|}{$6^{\text {th }}$ Irrigation } & \multicolumn{2}{|c|}{$9^{\text {th }}$ irrigation } \\
\hline & $\mathrm{T}_{0}$ & $\mathrm{~T}_{1}$ & $\mathrm{~T}_{0}$ & $\mathrm{~T}_{1}$ & $\mathrm{~T}_{0}$ & $\mathrm{~T}_{1}$ \\
\hline
\end{tabular}

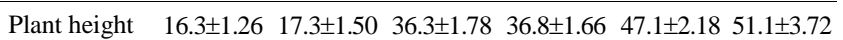
$\begin{array}{lllllll}\text { Branches/plant } & 1.5 \pm 0.28 & 1.7 \pm 0.21 & 2.1 \pm 0.32 & 2.4 \pm 0.36 & 2.9 \pm 0.34 & 3.5 \pm 0.41\end{array}$ Note: \pm is standard deviation.

Table 5 showed that the average number of branches per plant were recorded $1.59 \mathrm{~cm}, 2.15 \mathrm{~cm}$ and $2.9 \mathrm{~cm}$ of treatment $\mathrm{T}_{0}$ and $1.68 \mathrm{~cm}, 2.41 \mathrm{~cm}$ and $3.55 \mathrm{~cm}$ of treatment $\mathrm{T}_{1}$ on $3^{\text {rd }}, 6^{\text {th }}$ and $9^{\text {th }}$ irrigation respectively. Figure 2 showed the results of okra pods yield, which was $8,332 \mathrm{~kg} / \mathrm{hm}^{2}$ of $\mathrm{T}_{1}$ and $7,575 \mathrm{~kg} / \mathrm{hm}^{2}$ of $\mathrm{T}_{0}$ respectively. It showed an increase in using of plastic sheet in furrow irrigation at $\mathrm{T}_{1}$.

\subsection{Irrigation duration, volume and water saving}

The results for irrigation and time taken to fill each furrow strip at a required depth of $70 \%$ under both treatments were shown in Table 6. The applied irrigation water for each furrow of both treatments at every irrigation interval was calculated with cutthroat flume $\left(Q=0.005 \mathrm{~m}^{3} / \mathrm{s}\right)$. The total mean time taken by treatment $\mathrm{T}_{1}$ during irrigation was recorded as $540 \mathrm{~s}$, while for $\mathrm{T}_{0}$ irrigation method it was $780 \mathrm{~s}$. It was evident from the results that the total mean depth of irrigation water applied to each treatment block was $344.17 \mathrm{~mm}$ and $496.17 \mathrm{~mm}$, while the volume of water applied was noted $21.56 \mathrm{~m}^{3}$ and $31.09 \mathrm{~m}^{3}$ for treatments $\mathrm{T}_{1}$ and $\mathrm{T}_{0}$ respectively (Table 7). However, during crop growing phase, a rainfall of $0.17 \mathrm{~mm}$ was measured, which was further added in the total depth of water consumed under both treatments.

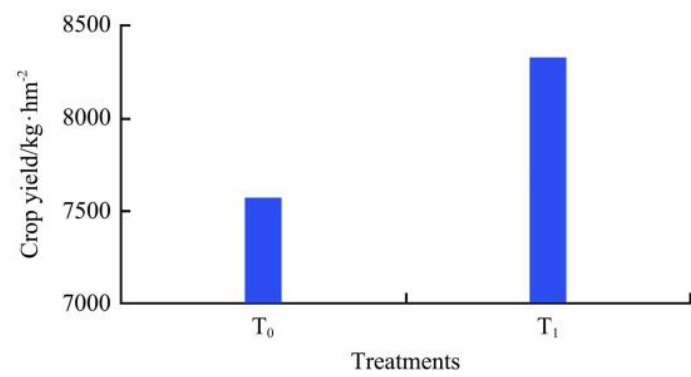

Figure 2 Crop yield for treatments $\mathrm{T}_{0}$ and $\mathrm{T}_{1}$

Table 6 Duration for irrigation application under both treatments

\begin{tabular}{|c|c|c|c|c|c|c|c|c|c|c|}
\hline \multirow[t]{2}{*}{$\begin{array}{c}\text { Number of } \\
\text { irrigation }\end{array}$} & \multicolumn{2}{|c|}{ Area $/ \mathrm{m}^{2}$} & \multicolumn{2}{|c|}{ Depth/mm } & \multicolumn{2}{|c|}{$\begin{array}{l}\text { Time taken } \\
\text { by each } \\
\text { furrow/sec }\end{array}$} & \multicolumn{2}{|c|}{$\begin{array}{c}\text { Number of } \\
\text { furrows }\end{array}$} & \multicolumn{2}{|c|}{$\begin{array}{l}\text { Total time } \\
\text { /sec }\end{array}$} \\
\hline & $\mathrm{T}_{0}$ & $\mathrm{~T}_{1}$ & $\mathrm{~T}_{0}$ & $\mathrm{~T}_{1}$ & $\mathrm{~T}_{0}$ & $\mathrm{~T}_{1}$ & $\mathrm{~T}_{0}$ & $\mathrm{~T}_{1}$ & $\mathrm{~T}_{0}$ & $\mathrm{~T}_{1}$ \\
\hline 08 & 62.7 & 62.7 & 62 & 43 & 130 & 90 & 6 & 6 & 780 & 540 \\
\hline
\end{tabular}

Table 7 Volume of irrigation application for both treatments

\begin{tabular}{cccccc} 
Treatments & $\begin{array}{c}\text { Recommended } \\
\text { depth water }\end{array}$ & Rainfall & $\begin{array}{c}\text { Total depth of } \\
\text { water applied }\end{array}$ & $\begin{array}{c}\text { Irrigated } \\
\text { area } / \mathrm{m}^{2}\end{array}$ & $\begin{array}{c}\text { Volume of } \\
\text { water used } / \mathrm{m}^{3}\end{array}$ \\
\hline $\mathrm{T}_{0}$ & 500 & 0.17 & 496.17 & 66 & 31.09 \\
$\mathrm{~T}_{1}$ & 500 & 0.17 & 344.17 & 66 & 21.56 \\
\hline
\end{tabular}

The total crop water required by okra crop in entire growing period under without plastic cover furrow bottom irrigation method was $500 \mathrm{~mm}$, while in the case of conventional flood irrigation methods it was $720 \mathrm{~mm}$. The mean water saving was determined $52.22 \%$ and $31.00 \%$ of $\mathrm{T}_{1}$ and $\mathrm{T}_{0}$ respectively, while compared to the water saving of flood irrigation method. Also, water saving was $30.64 \%$ under $\mathrm{T}_{1}$ as compared to that of $\mathrm{T}_{0}$ (Table 8).

Table 8 Irrigation water saving for both treatments

\begin{tabular}{|c|c|c|c|}
\hline \multirow{2}{*}{$\begin{array}{l}\text { Irrigation } \\
\text { methods }\end{array}$} & \multirow{2}{*}{$\begin{array}{l}\text { Irrigation } \\
\text { water }\end{array}$} & \multicolumn{2}{|c|}{ Water savings $/ \%$} \\
\hline & & $\begin{array}{l}\text { Compared with flood } \\
\text { Irrigation }\end{array}$ & $\begin{array}{c}\text { Compared with } \\
\mathrm{T}_{0}\end{array}$ \\
\hline $\mathrm{T}_{0}$ & 496 & 31.0 & - \\
\hline $\mathrm{T}_{1}$ & 344 & 52.2 & 30.6 \\
\hline Flood irrigation & 720 & - & - \\
\hline
\end{tabular}

\section{Discussion}

\subsection{Impact of plastic sheet on physic chemical properties of soil}

\subsection{1 $\mathrm{pH}$ and $\mathrm{EC}_{\mathrm{e}}$ of soil profile}

Table 4 showed that the $\mathrm{pH}$ of soil profile slightly decreased with the depth in upper soil layer in both experimental treatments. The soil $\mathrm{pH}$ decreased after harvest under $\mathrm{T}_{1} . \quad$ Decrease in $\mathrm{pH}$ was observed with respect to increasing $\mathrm{EC}_{\mathrm{e}}$ under $\mathrm{T}_{1}$, as the salts from upper to lower layer were not leaching down. It was observed that using plastic sheets laid on furrow bottom minimized the salts being leached. The $\mathrm{EC}_{\mathrm{e}}$ of soil profile depth was shown in Table 
4. $\mathrm{EC}_{\mathrm{e}}$ slightly increased under $\mathrm{T}_{0}$, but in the case for $\mathrm{T}_{1}$, there wasn't any increase observed. The reason behind was plastic sheet which stopped the infiltration from furrow bottom and diverted the downward movement of water to the sides of furrow ridge, leaving all soluble salts there. Similar study has been conducted $^{[35]}$ to observe the impact of plastic treatment on the soil hydraulic conductivity and chemical properties.

\subsubsection{Dry density of soil profile}

After the crop harvest, the mean soil dry density was increased $0.01 \mathrm{~g} / \mathrm{cm}^{3}$ under both treatments. These results of the experiment are matching to those reported by [36] and [37]. In upper soil layer the dry density of soil might increase with the preparation of surface layer crust, existing of sodium content with the dispersion of the clay soil with the consequent formation of fine pores.

\subsection{Plant height, number of branches per plant and crop yield}

Table 5 showed that the plant height and number of branches plant ${ }^{-1}$ under treatment $T_{0}$ were less than as compared to those under treatment $T_{1}$. The increase in plant height and number of branches plant ${ }^{-1}$ under $T_{1}$ might be due to more availability of soil moisture in the root zone and better nutrient use efficiency and their uptake by plants. The soluble nutrients might have not leached down due to zero infiltration rates below the furrow bottom, which was because the usage of plastic sheet provided the maximum opportunity for improving water and nutrient use efficiency for plants sown on ridges. Therefore, the plants sown on ridges under treatment $\mathrm{T}_{1}$ resulted in well developed root system, better growth, and higher plant height as compared to $\mathrm{T}_{0}$. Under treatment $\mathrm{T}_{0}$, excessive amount of water and soluble nutrients were washed out due to infiltration from furrow bottom, which might be the reason for poor plant growth. These results are supported by [38] who reported better root growth, plant height, fruit weight, nutrient uptake and yield in furrow method although there was non-significant effect between different sowing methods either on ridge or furrow on root growth. These results are similar to the previous study ${ }^{[38]}$ that they concluded the plastic sheet resulted in maximum plant height, earlier flower emergence, and the highest number of flower spikes per plant, floret per spike and flowers per plant. Additionally, these results are fully favored by [39] who reported plant height, the number of primary branches, the number of leaves and yield were better under plastic sheet mulched treatment as compared to those of control.

The performance overall was found to be the best in treatment $\mathrm{T}_{1}$ under furrow irrigation method using plastic sheets below furrow bottom (Figure 2). This may be due to availability of more soil moisture and soluble nutrients in the root zone where plastic sheets under furrow bottom were used, facilitating it to uptake and stopping leaching. Hence, it created better conditions for the growth and a well development of plant root system. Whereas because of leaching of sufficient amount of soluble nutrients, the yield for $T_{0}$ was observed to be less as compared to that of $T_{1}$. These results are supported by [40] which stated that the higher crop production with furrow irrigation method, it might be the reason that more phosphorus $(\mathrm{P})$ contents in the leaves, roots, and grains in furrow sown crop. The same results have also been stated by [38], which reported better yield harvested with furrow irrigation. These results are supported by [41], which studied the effect of plastic mulching and reported good effects on growth, yield and weed suppression. These results are also favored by [2] which reported better effects of mulch treatments on yield and yield ingredients. And the experimental results are fully supported by
[42] who applied colored plastic sheet and row covers and found better effects on the growth and yield of okra.

\subsection{Irrigation water volume and duration}

Table 7 showed the volume of irrigation water applied during the field study for the treatments $\mathrm{T}_{0}$ and $\mathrm{T}_{1}$ for growing okra crop. Irrigation water also included the amount of seasonal rainfall in volume of water used during the study. The total average time taken by treatment $T_{1}$ during irrigation to irrigate all the furrows to $70 \%$ of depth of furrow was less as compared to that by $\mathrm{T}_{0}$. The time of irrigation application was reduced due to plastic sheet which stopped the infiltration rate, allowing it consume less amount of water as compared to $T_{0}$. Under $T_{0}$ treatment, due to infiltration a large amount of water was being wasted and irrigation time increased. The results are matching with the findings ${ }^{[43]}$, which were reported that the sandy loam soil cause the low WUE with the excessive irrigation, deep percolation of the irrigation water and shortage of water in the critical stage of the crop. These results are similar to the results of [38], who concluded that in the management of soil, the use of mulch as protective cover placed over the soil could prevent water content, improve seed germination, deliver nutrients, and minimize the development of weeds. These outcomes are associated to[41], who reported better effects of plastic mulching on soil temperature, infiltration, and minimum water content losses under field conditions.

\subsection{Water saving}

Water saving (\%) for treatments $\mathrm{T}_{0}$ and $\mathrm{T}_{1}$ under the field experimental study was showed in Table 8 , and was compared with each other and flood irrigation method for okra crop. Results are in agreements with the findings by [12], who reported that vertical infiltration from the furrow decreased with the using of plastic sheet on furrow bottom and increased the water saving efficiency of furrow irrigation practice. Similar results have also been reported by [28], who stated that $22.73 \%$ to $40.38 \%$ increase in water saving efficiency with the use of plastic sheet as mulching in furrow irrigation method. These results are similar to those given by [44], who reported the WUE with plastic film was $2 \%-61 \%$ higher than non-plastic mulch. These results are also favored by [4], who reported that plastic mulched furrow increased $22.73 \%$ to $40.38 \%$ of saved water and the water saving efficiencies when compared to those of un-mulched (control) under furrow irrigation method.

\section{Conclusions}

The "Furrow irrigation method" is considered as an effective conventional irrigation practice, which is appropriate in regions where fresh water sources are limited. In this experimental study under furrow irrigation method it showed better performance with using of plastic sheet in associate with crop production and water saving.

Based on the study it was concluded that the use of plastic sheet in furrow irrigation practice has a slight effect on physicochemical properties in the soil profile at a depth of $0-80$, while the mean $\mathrm{pH}$ of soil decreased and soil salinity $\left(\mathrm{EC}_{\mathrm{o}}\right)$ increased under both treatments $\left(\mathrm{T}_{0}\right.$ and $\left.\mathrm{T}_{1}\right)$ after harvesting. However, the yield was higher under $T_{1}\left(8,332 \mathrm{~kg} / \mathrm{hm}^{2}\right)$ as compared to that under $\mathrm{T}_{0}\left(7,575 \mathrm{~kg} / \mathrm{hm}^{2}\right)$, while the saving of water was determined $31.00 \%$ and $52.22 \%$ under $\mathrm{T}_{0}$ and $\mathrm{T}_{1}$ respectively. Moreover, future research study may be conducted on different soils types under different crops in the regards with water saving and crop production under the use of plastic sheet at furrow bottom. 


\section{Acknowledgments}

Authors wish to thank the National Natural Science Foundation of China (Grant No. 51275250) for supporting. The first author is thankful to the Chinese Scholarship Council (CSC) for providing the scholarship to pursue Ph.D.

\section{[References]}

[1] Adnan Y, Muhammad Z M B, Atif R, Usman T, Muhammad A, Nadeem M, et al. Effect of different types of mulching on growth and flowering of Freesia alba cv. Aurora. Pak J Agr Sci, 2012; 49(4): 429-33.

[2] Hatami S, Nourjou A, Henareh M, Pourakbar L. Comparison effects of different methods of black plastic mulching and planting patterns on weed control, water-use efficiency and yield in tomato. Int J Agri Sci, 2012; 2(10): 928-34.

[3] Bhardwaj R L. Effect of mulching on crop production under rain-fed condition: A Review Int J Res Chem Environ, 2012; 2(2): 8-20

[4] Xiao Y L, Jia D G, Gao Q Z, Li F R. Incorporation of ridge and furrow method of rainfall arvesting with mulching for crop production under semiarid conditions. Agric Water Manage, 2001; 50(3): 173-183.

[5] Bainbridge D A. Buried clay pot irrigation: A little known but very efficient traditional method. Agric Water Manage, 2001; 48(2): 79-88.

[6] Mamkagh A M, A Salmerón, García Y, Real AI. Effect of tillage time and plastic mulch on growth and yield of okra (Abelmoschusesculentus) grown under rain-fed conditions. Int J Agri Bio, 2009; 11(4): 453-457.

[7] Maqsood M, Shehzad M A, Mohsin A. Seed rate effects on fodder yield and quality attributes of maize (Zea mays L.) varieties sown under irrigated conditions. Pak J Agr Sci, 2012; 49(2): 155-162.

[8] Patel B R, Patel K B, Parikh M M. Evaluation and comparison of drip, sprinkler and surface irrigation methods for water saving and yield improvement with cabbage okra and sugarcane crops. 60th International Executive Council Meeting and 5th Asian Regional Conference; New Delhi, India 2009

[9] A N, Ghulam R. Irrigated agriculture of Pakistan. Lahore, Pakistan 1988.

[10] Pravukalyan P, Narendra N S, Sanatan P. Evaluating partial root-zone irrigation and mulching in okra (Abelmoschusesculentus L.) under a sub-humid tropical climate. J Agr Rural Dev Trop, 2011; 112(2): 169-175.

[11] Rafiq M. Irrigation and drainage practice for agriculture. University of Faisalabad: Study Aid Project 2005.

[12] Altaf A, Siyal, Bristowc K L, Simunek J. Minimizing nitrogen leaching from furrow irrigation through novel fertilizer placement and soil surface management strategies. Agric Water Manage, 2012; 115: 242-251.

[13] Robert M H. Irrigation of Agriculture Lands. Amr Soci Agron, 1967; 7: 577-597.

[14] Israelsen O W, Hansenand V E, Stringham G E. Irrigation principles and practices. Inc., New York: 4th edition 1980.

[15] Jones C, Jacobsen J. Fertilizer placement and timing. Nutrient Management. Module No 11 Montana State University, Bozeman, USA. 2009.

[16] Yonts C D. Firming irrigation furrows to improve irrigation performance. NebGuide. University of Nebrask: The Board of Regents. 2007.

[17] Mugnozza S. Current status of plastic culture in Europe. 35th National Agricultural Plastics Congress; State College, Pennsylvania, USA 2009. p. 25.

[18] Al-Rawahy S A, Al-Dhuhli H S, Prathapar S A, AbdelRahman H. Mulching material impact on yield, soil moisture and salinity in saline-irrigated sorghum plots. Int J Agric Res, 2011; 6(1): 75-81.

[19] Akinbile C O, Yusoff M S. Effect of tillage methods and fertilizer applications on amaranthus curentus in Nigeria. Int J Agri Res, 2011; 6: 280-289.

[20] Fisher P D An alternative plastic mulching system for improved water management in dry land maize production. Agr Water Manage, 1995; 27(2): 155-166.

[21] Bristow K. The role of mulch and its architecture in modifying soil temperature. Soil Res, 1988; 26(2): 269-280.

[22] Rodrigues E J R, Keigo M, Pnrico F. Mulching in soilless system of the rose crop: Productivity, water consumption, temp: and salinization. Sci Agricol, 1999; 56: 785-795.

[23] Jin M G, Zhang R Q, Sun L, Gao U F. A case study in the Heilongiiang region. Agric Water Manage, 1999; 42(2): 173-187.

[24] Bai X, Wei Z X, Guo H Q, He Z H, Xu G P. Research on farmland's moisture dynamic changes of micro-water harvesting planting technique in the northwestern of Shanxi Province. J Shanxi Agri Uni, 2005; 25(3): 289-291. (in Chinese)

[25] Wang J, Li F, Song Q, Li S. Effects of plastic film mulching on soil temperature and moisture and on yield formation of spring wheat. Chinese Journal of Applied Ecology, 2003; 14(2): 205-212. (in Chinese)

[26] Fang R, Tong Y, Liang D, Fang J. Effect of different mulching on spring corn yield and on soil environment in Loess Plateau. Chinese Journal of Applied Ecology, 2003; 14(11): 1897-1900. (in Chinese)

[27] Wang H L, Zhang X C, Song S Y, Ma Y F, Yu X F, Liu Y. Effects of whole field-surface plastic mulching and planting in furrow on soil temperature, soil moisture, and corn yield in arid area of Gansu Province. Northwest Chin Chinese Journal of Applied Ecology, 2011; 22(10): 8-14. (in Chinese)

[28] Jiang S, Gao X, Liang J, Wang P, Gao J, Qu Y, et al. Effect of different furrow and mulched ridge on water moisture conversation and water saving of spring mung bean planted farmland. J Agric Science, 2012; 4(7): 132-141.

[29] Li R, Hou X Q, Jia Z K, Han Q F, Yang B P. Effects of rainfall harvesting and mulching technologies on soil water, temperature, and maize yield in Loess Plateau. Soil Res, 2012; 50(2): 105-113.

[30] MINFAL. Training manual for the training of On Farm Water Management (OFWM) Staff, 2005.

[31] Dabiré B, Ba C L, Somé M N, Sanon K. Preliminary studies on incidence of insect pest on okra, Abelmoschusesculentus (L.) Moench in central Burkina Faso. Afr J Agri Res, 2009; 7(4): 1488-1492.

[32] Bouyoucos G J. Directions for making mechanical analysis of soils by the hydrometer method. Soil Sci, 1936; 4(3): 225-230.

[33] McIntyre D S, Loveday J. Bulk density, methods of analysis for irrigated soils. Loveday Je, editor. Farnham Royal, England, 1974.

[34] Rowell D L. The preparation of saturation extracts and the analysis of soil salinity and sodicity. In soil science methods and applications. Rowell, editor. UK: Longman Group, 1994.

[35] Chen Y, Katan J. Effect of solar heating of soils by transparent polyethylene mulching on their chemical properties. Soil Sci, 1980; 130(5): 1-20

[36] Frenkel H, Goertzen J O, Rhoades J D. Effects of clay type and content exchangeable sodium percentage, and electrolyte concentration on clay dispersion and soil hydraulic conductivity. Soil Sci Soc Am J, 1978; 42: 32-39.

[37] Kazman Z, Shainberg I, Gal M. Effect of low levels of exchangeable sodium and applied phospho-gypsum on the infiltration rate of various soils. Soil Sci, 1983; 135(3): 84-92.

[38] Khan M.B, R Rafiq, M Hussain, Farooq M, Jabran K. Ridge sowing improves root system, phosphorus uptake, growth and yield of maize (zeamays 1.) hybrids. J Anim Plant Sci, 2012; 22(2): 309-317.

[39] Ashrafuzzaman M A H, Ismail M, Mohd R S, Alamgir S M, Hossain M Effect of plastic mulch on growth and yield of chilli (Capsicum annuum L.) Braz Arch Biol Technol, 2011; 54: 321-330.

[40] Hussain M, Farooq M, Jabran K, Wahid A. Foliar application of glycinebetaine and salicylic acid improves growth, yield and water productivity of hybrid sunflower planted by different sowing methods. J Agron Crop Sci, 2010; 196: 136-145.

[41] Awodoyin R O, Ogbeide F I, Olufemi O. Effects of three mulch types on the growth and yield of tomato (Lycopersiconesculentum Mill.) and weed suppression in Ibadan, rainforest-savanna transition zone of Nigeria. J Ibadan Uni Nigeria, 2007; 37(3): 117-125.

[42] Garry G, Gordon F, Wheeler G, Foshee H, Stewart T, James E, et al. The effects of colored plastic film mulches and row covers on the growth and yield of Okra. Horttechnology, 2010; 20(1): 224-233.

[43] Brown J E, Butcher C C. Effect of three row covers and black plastic mulch on the growth and yield of 'Clemson Spineless' okra. J Veg Crp Prod, 1999; 5(2): 67-71.

[44] Zhong K X, Wang Y, Li F. Effect of plastic mulching on soil water use and spring wheat yield in arid region of northwest China. Agric Water Manage, 2004; 75: 71-83.

[45] Memon M S, Zhou J, Guo J, Ullah F, Hassan M, Ara S, Ji C Y. Comprehensive review for the effects of ridge furrow plastic mulching on crop yield and water use efficiency under different crops. Int Agri Eng J, 2017; 26(2): 58-67. 